\title{
THE LAWYER'S DUTY OF CANDOR AND FAIRNESS A DUTY TO CONFESS?*
}

RESPECT for the administration of justice depends in large measure on the maintenance of the highest standards of professional conduct by the members of the bar. ${ }^{1}$ When these standards are not enforced, the public must bear the burden of inadequate or irresponsible representation, vexatious litigation, and the perversion of justice by delay, corruption, and negligence. The lawyer, therefore, in his capacity as advocate, counselor, and officer of the court, must be prepared to submit to continuing supervision and periodic investigation by the bench. At the same time, lawyers, like other citizens, are guaranteed certain rights and privileges by state and federal constitutions. The exercise of these rights may interfere with the court's efforts to supervise the conduct of its bar.

This issue recently confronted the New York Court of Appeals in Matter of Cohen, ${ }^{2}$ where an attorney's exercise of his privilege against self-incrimination was alleged to violate his professional duty to cooperate in a judicial inquiry into "ambulance chasing."3 When called before the inquiry, Cohen was told that the hearing was merely investigative and was not a disciplinary proceeding against him personally; he was to be questioned on matters within the scope of the inquiry relating to his professional conduct. Cohen was also informed that counsel for the inquiry had "information" indicating his participation in professional misconduct, although the only evidence introduced at this or later proceedings consisted of three hundred and four "statements of retainer," which Cohen had filed under prevailing court rules. ${ }^{4}$ On the

*Matter of Cohen, 7 N.Y.2d 488, 199 N.Y.S.2d 658, 166 N.E.2d 672 (1960), cert. granted sub nom. Cohen v. Hurley, 363 U.S. 810 (1960).

1. See Preamble, Canons of Professional Ethics [hereinafter cited individually as Canons] in N.Y. JudrClaRy LAw, appendix 765 (1948), and in BRANd, Bar Associations, AtroRNeYs AND JUDges 797 (1956).

2. 7 N.Y.2d 488, 199 N.Y.S.2d 658, 166 N.E.2d 672 (1960), cert. granted sub nom. Cohen v. Hurley, 363 U.S. 810 (1960).

3. Prompted by charges of illegal, corrupt, and unethical practices, and of conduct prejudicial to the administration of justice, allegedly rife within the legal profession in the County of Kings, the inquiry purposed "to expose all the evil practices with a view to enabling this court to adopt appropriate measures to eliminate them and to discipline those attorneys found to have engaged in them." Matter of Cohen, 9 App. Div. 2d 436, 437, 195 N.Y.S.2d 990, 993 (1959).

"Preliminary investigations" into charges of professional misconduct are authorized by N.Y. Judiciary LaW $\S 90(6)$. See note 39 infra.

For an historical review of the court's power to investigate professional misconduct and compel testimony "subject to claim of privilege," see People ex rel. Karlin v. Culkin, 248 N.Y. 465, 474-77, 162 N.E. 487, 490-92 (1928) (Cardozo, J.).

4. For text of the rule requiring submission of statements of retainer, see Special Rules Regulating the Conduct of Attorneys and Counselors at Law in the Second Judicial Department, in Clevenger's Practice Manual rule 3, p. 19-21 (1959). 
advice of counsel, Cohen claimed his privilege against self-incrimination under the New York Constitution ${ }^{5}$ and refused to produce subpoenaed documents or to answer certain questions, despite warnings by the court that his refusal might lead to disciplinary proceedings. The questions related to the identity of his law office partners, associates, and employees, to his possession of the records of the cases described in his statements of retainer, to the destruction of such records, to his bank accounts, to payments to police officers, insurance company employees, or others for referring claimants to him, to promises to pay to any lay person ten per cent of recoveries or settlements, and to whether one of his partners or associates had pleaded guilty to soliciting legal business or employing "solicitors," a violation of the Penal Law. ${ }^{6}$ The presiding justice thereafter recommended to the Appellate Division that disciplinary proceedings be instituted against Cohen. In the hearings that followed, Cohen admitted exercising his privilege against self-incrimination in response to concededly relevant questions. The good faith of his refusal to answer was at no time questioned. On the basis of these facts Cohen was disbarred, with leave to re-enter the bar should he present himself before the judicial inquiry within thirty days and answer such questions as might properly be put to him. ${ }^{7}$

The Court of Appeals affirmed in a divided opinion. The majority conceded that Cohen had a right, as a citizen, to assert the privilege and to withhold any answers which might incriminate him. But, said the court (quoting Judge Cardozo's opinion in Matter of Rouss), "Membership in the bar is a privilege burdened with conditions.... Whenever the condition is broken the privilege is lost." " Among these conditions, the court declared, were the Canons admonishing lawyers to inform the court of professional misconduct on the part

5. Article 1, 8 , N.Y. Const. provides:

No person shall be ... compelled in any criminal case to be a witness against himself, providing, that any public officer who, upon being called before a grand jury to testify concerning the conduct of his office or the performance of his official duties, refuses to sign a waiver of immunity against subsequent criminal prosecution, or to answer any relevant question concerning such matters before such grand jury, shall by virtue of such refusal, be disqualified from holding any other public office or public employment for a period of five years, and shall be removed from office by the appropriate authority or shall forfeit this office at the suit of the attorney general .... No person shall be deprived of life, liberty or property without due process of law.

6. Canons 28 and 29 forbid payment to persons for soliciting legal business and require lawyers to report such practices to the court; Canon 34 outlaws fee-splitting with nonlawyers. Soliciting and fee-splitting are also criminal offenses. N.Y. PEN. LAW $\$ \$ 270-a$, 270-d, 276 (1944).

7. Order of Disbarment by Appellate Division, 2d Dep't, Dec. 31, 1959, in Petition for Writ of Certiorari, p. 66-67, Cohen v. Hurley, 363 U.S. 810 (1960). The disbarment order was stayed pending appeal to Court of Appeals. Cohen v. Hurley, 10 App. Div. 2d 581, 196 N.Y.S.2d 277 (1960).

8. Matter of Rouss, 221 N.Y. 81, 84-85, 116 N.E. 782, 783 (1917) quoted, in inverse order, in Matter of Cohen, 7 N.Y.2d at 495, 199 N.Y.S.2d at 662, 166 N.E.2d at 675. 
of others ${ }^{9}$ and to be candid and fair with the court at all times. ${ }^{10}$ Therefore, Cohen was not disciplined for invoking his constitutional privilege, but because he had breached his "inviolable and absolute duty to co-operate with the court in a valid and proper investigation of unethical practices."11 Similar restrictions upon public employees were cited, ${ }^{12}$ apparently as authority for placing this restraint upon the legal profession.

The court's construction of the state self-incrimination clause would be subject to federal review only if arbitrary or discriminatory. ${ }^{13}$ Even if it cannot be attacked on these grounds, however, the importance of the privilege claimed and the severity of the sanction imposed for its exercise warrant further inquiry into the propriety of the court's decision. The New York decision "preserves" the lawyer's right against self-incrimination by leaving him an almost impossible choice: if he remains silent, he may be disbarred; if he speaks, he may be subject to criminal prosecution. The threat of being forced to abandon an established legal practice has such coercive force that, practically, the attorney must confess or explain all his actions to the inquiring tribunal.

This result has been rejected by the two other states which have considered this problem directly, as well as by earlier New York decisions. ${ }^{14}$ In Sheiner v. State, ${ }^{15}$ the Florida court reversed an order of disbarment based on the

9. Canon 29.

10. Canon 22.

11. 7 N.Y.2d at 492,199 N.Y.S.2d at 660,166 N.E.2d at 674. (Emphasis added.)

12. Id. at 496,199 N.Y.S.2d at 663,166 N.E.2d at 676 . The court cited Beilan v. Board of Education, 357 U.S. 399 (1958) (school teacher dismissed for "incompetency"); Lerner v. Casey, 357 U.S. 468 (1958) (subway conductor dismissed for "doubtful trust and reliability") ; Nelson v. County of Los Angeles, 362 U.S. 1 (1960) (county employee dismissed for "insubordination").

13. The privilege against self-incrimination is not a requisite of due process. Twining v. New Jersey, 211 U.S. 78 (1908) ; Adamson v. California, 332 U.S. 46 (1947).

The privilege having been created by state law, it remains for the state to define the scope of its protection. Under the prevailing view in both federal and state jurisdictions, these limitations were not overstepped in Cohen by holding that the privilege itself provided protection only from criminal prosecution and not from noncriminal sanctions such as professional discipline. McCormick, Evidence $\S 128$ (1954); 8 Wigmore, EviDENCE $\$ 2254$ (3d ed. 1940), $\$ 2255$ (Supp. 1959) (both citing cases).

14. But see Matter of Fenn, 235 Mo. App. 24, 128 S.W.2d 657 (1939).

15. 82 So. $2 \mathrm{~d} 657$ (Fla. 1955).

Sheiner may be distinguishable, however, because, in part of the opinion, the court seems to consider the issue to be the validity of drawing inferences from the claim of privilege:

If any court can hold that appellant's refusal to answer the query, whether he is now or ever was a member of the Communist Party, supported by nothing more than the evidence taken by the Congressional Committee ... and inferences therefrom, is sufficient to disbar him, then one's privilege to practice law may be made to depend on a very tenuous thread .... I do not think the state can abandon proof of charges against an attorney for unprofessional conduct and disbar him on grounds that he challenges and that are not proven.

Id. at $660-61$. 
exercise of the privilege both before a congressional subcommittee and during subsequent disbarment proceedings. In In re Holland, ${ }^{16}$ the Illinois court reversed the suspension of a lawyer who had allegedly exercised the privilege in bad faith before a grand jury, after concluding that the privilege had in fact been claimed in good faith. In both these cases it was held that the exercise of the privilege, without more, would not support disciplinary action. Two earlier New York cases, Matter of Grae ${ }^{17}$ and Matter of Ellis ${ }^{18}$ held that a lawyer could not be disbarred for refusing to waive his statutory immunity before being questioned. ${ }^{19}$ Both cases involved judicial inquiries into professional misconduct. This policy also seemed to govern in two other New York cases, where attorneys who exercised the privilege before a grand jury ${ }^{20}$ and during a criminal trial ${ }^{21}$ were held immune from disciplinary action. While the Colten court distinguished Grae and Ellis, it admitted that the distinction was "slight" and was being used as an opportunity to "re-examine" the question in issue. ${ }^{22}$

In performing this re-examination, however, the New York court failed to articulate and to weigh the policies involved in this unprecedented disciplinary procedure. The court's reliance upon government employee cases, induced perhaps by literal adherence to the "court officer" notion, does not suffice. Other courts, in resolving similar problems, have recognized that lawyers cannot be classified with government employees: lawyers are neither paid by the government, nor are they expected to adhere in employee-like fashion to the policy directives of superiors. ${ }^{23}$ Even less guidance is furnished by the court's

16. 377 Ill. 346,36 N.E.2d 543 (1941).

17. 282 N.Y. 428,26 N.E.2d 963 (1940).

18. 282 N.Y. 435, 26 N.E.2d 967 (1940).

19. Both cases have been widely cited for the proposition that the exercise of a constitutional right cannot be a breach of duty to the court. See $I n$ re Holland, 377 IIl. 346, 353-54, 36 N.E.2d 543, 547 (1941) ; Sheiner v. State, 82 So. 2 d 657, 661-62 (Fla. 1955); In re the Integration Rule of the Florida Bar, 103 So. 2d 873, 875 (Fla. 1956); Koenigsberg v. State Bar California, 353 U.S. 252, 270 (1957) ; Note, 8 ALA. L. Rev. 358, 360 (1956); Note, 16 LA. L. REv. 577, 580 (1956).

20. In re Solovei, 250 App. Div. 117, 293 N.Y. Supp. 640 (1937), aff'd, 276 N.Y. 647, 12 N.E.2d 802 (1938). Since the precise question was, as in Grae and Ellis, refusal to waive immunity, the court in Colhen might have distinguished Solovei on that ground. See note 22 infra. The court, however, chose to distinguish it because a different forum was involved. See note 31 infra.

21. In re Kaffenburgh, 188 N.Y. 49, 80 N.E. 570 (1907) (dictum-disbarment affirmed on other grounds).

22. The precise question in Grae and Ellis ... was as to whether a lawyer who offered to answer all pertinent questions could be compelled in such an investigation to waive immunity in advance of questioning.

7 N.Y.2d at 497,199 N.Y.S.2d at 664,166 N.E.2d at 677.

23. Cammer v. United States, 350 U.S. 399, 405 (1956) (attorneys distinguished from other officers of the court such as marshals, bailiffs, clerks, and judges in that attorneys are "engaged in a private profession, important though it be to our system of justice"); Ex parte Garland, 71 U.S. (4 Wall.) 333, 378 (1866) ("The profession of an attorney 
conclusionary statement that membership in the bar is a "privilege burdened with conditions," since the reasons for the particular "condition" imposed in Cohen are not explored.

Conditions or duties imposed upon the lawyer should be reasonably related to maintaining those qualities of the bar which are essential to the proper performance of its role in the administration of justice. ${ }^{24}$ But even those forms of conduct which are properly labeled "conditions" may in particular instances be waived in order to preserve a more important countervalue. Certainly the lawyer's duty to "co-operate with the court" or to be "candid and fair" cannot be said to be "absolute and inviolate" in the sense that it requires his compliance with every demand of a particular judicial incumbent. ${ }^{25}$ As but one example, the lawyer's duty of "entire devotion to the interests of the client" within the boundaries of the law, ${ }^{26}$ combined with the lawyer-client privilege, ${ }^{27}$ could justify his withholding information which would be helpful to the administration of justice. Although this example does not dispose of the problem in Cohen, it does indicate that the extent of a lawyer's duty to "cooperate" can only be determined by evaluating the effects of silence and disclosure upon the countervailing ends served by each.

The lawyer's duty to be candid and fair with the court owes its existence to the role he plays in judicial proceedings: the court must place great confidence in the competence and integrity of his presentation of cases, his argument, and his reference to authority. To cite a case or statute known to be inapplicable, to fail to call to the court's attention a case or statute known to be controlling, or wilfully to falsify or suppress evidence is to mislead the court. ${ }^{28}$ Such conduct frustrates the dispensation of justice in the particular case and in turn, by destroying public faith in the bar and the courts, threatens

and counsellor is not like an office created by an act of Congress, which depends for its continuance, its powers, and its emoluments upon the will of its creator ... ."); In re Holland, 377 Ill. 346, 358, 36 N.E.2d 543, 549 (1941) (lawyer's duty to investigate crime distinguished from that of policeman) ; cf. Sowers v. Wells, $150 \mathrm{Kan} .630,633,95$ P.2d 281, 283-85 (1939) (attorneys distinguished from "public officers"); In re Galusha, 184 Cal. 697, 698, 195 Pac. 406 (1921) ("attorneys are not public officers, but are engaged in a private profession pursued primarily for pecuniary profit").

24. See Theard v. United States, 354 U.S. 278, 281 (1957).

25. "It is the duty of the lawyer to maintain towards the Courts a respectful attitude, not for the sake of the temporary incumbent of the judicial office, but for the maintenance of its supreme importance ...." Canon 1.

26. Canon 15.

27. The privilege actually belongs to the client. Thus, if the client waives the privilege, it cannot be claimed for the benefit of anyone else, including the attorney. McCoRMICK, EvideNCE $\$ 96$ (1954); 8 Wigmore, Evidence $\$ 2321$ (3d ed. 1940). On the other hand, the attorney not only may refuse to divulge the protected confidences of the client; under the rule and its supporting statutes he must so refuse unless the client waives the privilege or the court rules against it. Ibid.

28. Canon 22; see Vickers v. State Bar, 32 Cal. 2d 247, 196 P.2d 10 (1948); In rc Williams, 221 Minn. 554, 23 N.W.2d 4 (1946). See generally Jessup, The Professronal IDEALS OF THE LAWYER 17 (1925). 
to undermine the administration of justice generally. When the lawyer appears as a witness in court or before a judicial inquiry, however, his duty of candor and fairness should be read in the light of the role he is then playing. When the lawyer testifies as to observed fact, the court need place no special reliance on him because of his training or experience. As a witness, only his abilities to observe, recall, and narrate the facts are important, and disclosure cannot be said to be more important merely because the witness has a legal degree. Of course, the lawyer may be disciplined for false testimony, but here discipline is invoked because deceit reveals moral turpitude, ${ }^{29}$ not because it involves any abuse of the lawyer's peculiar relationship to the court. Similarly, when a lawyer claims his privilege not to answer, he does not mislead the court or violate a special judicial confidence; rather, his refusal calls attention to the fact that the court's data of decision is incomplete. Moreover, the privilege being incontestably available to all citizens, including lawyers, its exercise cannot be equated with moral turpitude.

The New York Court of Appeals seems to have recognized this limitation in some circumstances, for it has not applied the duty of candor to lawyerwitnesses testifying at trial or before the grand jury. ${ }^{30}$ By distinguishing those cases from Cohen, however, on the basis of the difference in the proceeding involved, ${ }^{31}$ the court has implied that the general inquiry into professional misconduct differs from other judicial proceedings and that extension of the duty to be candid is somehow justified in this case. The distinction between trials and general inquiries cannot rest upon a greater likelihood of deceit, for the lawyer is the same kind of witness in both proceedings. Nor can the privilege against self-incrimination be any less applicable in the general inquiry; as the court itself admitted, ${ }^{32}$ the privilege is available in any proceeding in which the information sought could be used in a criminal prosecution. ${ }^{33}$ The most likely justification for the distinction is a practical one: the general inquiry cannot function effectively without full disclosure by its witnesses. Although both

29. See N.Y. Judictary LAw $\$ 90(2)$; Ex parte Wall, 107 U.S. 265, 283 (1882) : No question can be made of the power of a court to strike a member of the bar from the roll for official misconduct. ... We do not mean to say that there may not be cases of misconduct not strictly professional, which would clearly show a person not fit to be an attorney, nor fit to associate with honest men. Thus, if he was proved to be a thief, a forger, a perjurer, or guilty of other offenses of the crimen falsi.

30. See notes 20-21 supra and accompanying text.

31. "Kaffenburgh's refusal to testify was at a criminal trial . . and Solovei's was before a grand jury." 7 N.Y.2d at 497, 199 N.Y.S.2d at 664, 166 N.E.2d at 677.

32. 7 N.Y.2d at 495,199 N.Y.S.2d at 662,166 N.E.2d at 675.

33. In the Matter of Rouss, 221 N.Y. 81, 86, 116 N.E. 782, 784 (1917) (disbarment proceedings); see Smith v. United States, 337 U.S. 137 (1949) (administrative hearing); McCarthy v. Arndstein, 266 U.S. 34 (1924) (civil proceedings); Phleps v. Phleps, 133 N.J. Eq. 392, 32 A.2d 81 (Ct. Err. \& App. 1943) (deposition); State v. Kemp, 126 Conn. 60, 9 A.2d 63 (1939) (grand jury); In the Matter of Doyle, 257 N.Y. 244, 177 N.E. 489 (1931) (legislative committee hearing). 
the grand jury and the general inquiry often investigate problems of widespread misconduct, counsel for the general inquiry may receive less investigative assistance from the state's law enforcement agencies $;^{34}$ therefore, he may not have the resources necessary to investigate each suspected offender. The imposition of a duty to confess is one way to compensate for this lack of information.

On the other hand, the preservation of the safeguards of individual liberty, and the control of inquisitorial methods are ends which would be served by upholding the right of silence. Our society has so highly regarded the selfincrimination privilege as to elevate it to constitutional status in all but two states. $^{35}$ The practical necessity for this privilege is particularly apparent in broad general inquiries such as the one in Cohen. An "inviolable" duty to disclose facts on demand can be utilized to purge the bar of members suspected of substantive misconduct without ever offering proof of their offense. If many attorneys are subjected to questioning, perhaps on the basis of nothing more than rumor, suspicion, or hunch, a certain number may be forced to invoke the self-incrimination privilege when, notwithstanding their innocence, their answers would contribute to a circumstantial case against them. If they may then be disbarred for "lack of candor," the disciplinary authority need never justify its inquiry or confront the attorneys with any evidence of the suspected substantive misconduct, thus depriving the attorneys of an opportunity to rebut or explain. Moreover, the possibility under the Cohen rule of disbarring without proof of misconduct affords an opportunity to persecute attorneys for conduct or beliefs not officially proscribed but nevertheless unpopular. While such abuses need not occur if officials act with restraint and integrity, a system of justice which must rely upon the self-restraint of officials is foreign to the entire heritage of procedural due process. ${ }^{36}$

34. Two factors may dictate this result: first, to those directing the police and other official investigative agencies, the problem of "ambulance chasing" or other unprofessional conduct, even if it is also criminal, may not compare in urgency with the problem of combating other types of crime, either because of the official's subjective evaluation of the problem or because greater public pressure is centered on the other forms of crime; and second, it must be recognized that the day-to-day concern of police and other investigators of established agencies is with activities other than lawyer misconduct, thus minimizing the routine accumulation of evidence. These factors are, of course, interrelated.

On the other hand, it should be noted that these official investigative resources are not of equal value to all criminal investigations. For example, in investigating such white-collar crimes as embezzlement, tax fraud, or conspiracy to violate anti-trust laws, a grand jury might benefit somewhat from a preliminary screening of potential witnesses, but its principal reliance must, like that of judicial inquires into unethical conduct, be placed on the power to compel testimony and the production of documents.

35. See Twining v. New Jersey, 211 U.S. 78, 92 (1908). The two exceptions are New Jersey and Iowa, and both those states have codified the privilege. N.J. REv. Stat. \$ 81-5 (Supp. 1952); Iowa Cone ANN. \$ 622.14 (1950).

36. Under any system which permits John Doe to be forced to answer on the mere suspicion of an officer of the law, or on public rumor, or on secret betrayal, two 
The duty to confess would doubtless expedite the disciplinary process. Whether it would promote the proper administration of justice more than its ultimate abuse would degrade the process is doubtful. In light of this doubt, therefore, the court ought first to consider whether the existing procedures for investigation are in fact so inadequate that they force this difficult choice. If the interests of society, court, and lawyer can all be accommodated by a procedure less subject to abuse, the Cohen rule should be rejected.

These interests might be accommodated, without resort to the artificial charge of "lack of candor," by the use of other commonly accepted and less severe sanctions for refusal to answer. Disbarment for substantive misconduct is often made possible by a refusal to answer. Several jurisdictions have held that an attorney's silence in the face of substantial evidence of misconduct permits the indulgence of, ${ }^{37}$ or even "irresistably impels,"38 the most unfavorable inferences from the credible evidence before the court. When a court conducting a general inquiry is faced with an "uncooperative" witness, it could make use of this sanction by introducing evidence of the lawyer's misconduct and then interrogating him again about that conduct. If the independent evidence were sufficient to permit an inference of misconduct, that inference could be established conclusively by the witness's continued refusal to answer relevant questions. This procedure, in effect, temporarily turns the general inquiry into a preliminary disciplinary proceeding ${ }^{39}$ against the reluctant witness. In the disbarment proceedings which follow, the attorney's attack upon the presumption of misconduct could be limited to demonstrating that the independent evidence presented below could not logically support the inference of misconduct. In this manner, the witness would be disciplined only for substantive

abuses have always prevailed and inevitably will prevail; first, the petty judicial officer becomes a local tyrant and misuses his discretion for political or mercenary or malicious ends; secondly, a blackmail is practiced by those unscrupulous members of the community .... .

8 WigMore, EVIDENCE $\$ 2251$ (3d ed. 1940).

A similar observation was made with regard to due process requirements in criminal procedure by Mr. Justice Frankfurter:

A democratic society, in which respect for the dignity of all men is central, naturally guards against the misuse of the law enforcement process. Zeal in tracking down crime is not in itself an assurance of soberness of judgment. Disinterestedness in law enforcement does not alone prevent disregard of cherished liberties. Experience has therefore counseled that safeguards must be provided against the dangers of the overzealous as well as the despotic.

McNabb v. United States, 318 U.S. 332, 343 (1943).

37. In the Matter of Fenn, 235 Mo. App. 24, 128 S.W.2d 657 (1939) (failure to take the stand); $c f .8$ WIGAIORE, EVIDENCE $\$ 2272$ (5) (3d ed. 1940) (civil action).

38. In re Wellcome, 23 Mont. 450, 468, 59 Pac. 445, 452 (1899), cited with approval by In re Vaughan, 189 Cal. 491, 496, 209 Pac. 353, 355 (1922), and in turn by Fish v. State Bar, 214 Cal. 215, 222, 4 P.2d 937, 940 (1931).

39. Actually, according to one reading of the enabling statute, only hearings and investigations relating to charges are authorized. N.Y. JuDICIARY LAw $\S 90(6)$. 
misconduct, and not for claiming the privilege against self-incrimination. Admittedly, this sanction could not be applied when the information sought was not related to the lawyer's own misconduct; a refusal to answer questions about one set of facts cannot affect the inference drawn from another unrelated set of facts. Nor would this sanction be helpful if the court of inquiry has no independent evidence of misconduct. But in either of these cases, the court would be alerted to the possibility of misconduct and could thereafter investigate the lawyers who claimed the privilege. In this way, the inquiry would act as a screen to narrow down the number of suspects and would thus ease the investigative burden. Moreover, to the extent that discipline for a refusal to answer is actually grounded on an unspoken belief that the witness was guilty of the alleged misconduct, ${ }^{40}$ the suggested procedure recognizes the reason for discipline and requires proof of it.

Other factors which discourage a claim of privilege should also be considered. The lawyer must always be circumspect in refusing to answer because a claim of privilege unsupported by reasonable fear of criminal prosecution would itself be grounds for disbarment. Moreover, the lawyer must also consider the likelihood that a refusal to answer will trigger a thorough investigation of his professional affairs, which in turn may result in the loss of personal and professional reputation, professional discipline, and even criminal sanctions. Even if the accused lawyer is guilty of misconduct, he may be induced to answer by the tendency of courts to regard full disclosure as evidence of atonement which warrants less severe discipline. For example, a New York court considered a two-year suspension adequate discipline in the case of a lawyer accused of ambulance chasing who "had done nothing to impede the court's investigation ... but, on the contrary, has been open and frank in his statements," even though, "as a general rule . . the lawyer who engages in 'ambulance chasing' disqualifies himself from the practice of law."42

40. If the attorney could prove that the disbarment had in fact been based upon such a belief, or inference, the disbarment would violate due process. See Konigsberg v. State Bar of California, 353 U.S. 252 (1957) (admission to the bar) ; Slochower v. Board of Higher Education, 350 U.S. 551, rehearing denied, 351 U.S. 944 (1956) (dismissal from teaching position). The difficulty, however, is that the proof fails if the words used by the court disclaim any resort to the drawing of inferences. See Nelson v. County of Los Angeles, 362 U.S. 1 (1960) ; Beilan v. Board of Education, 357 U.S. 399 (1958) ; Lerner v. Casey, 357 U.S. 468 (1958).

In Cohen, the Court of Appeals was careful to avoid drawing any inferences from the claim of privilege. See 7 N.Y.2d at 497, 199 N.Y.S.2d at 664, 166 N.E.2d at 677.

41. In the Matter of Levy, 255 N.Y. 223, 225, 174 N.E. 461, 462 (1931). Care must be taken, however, to be judicious in applying the label of bad faith to a claim of privilege, as will be apparent from a reading of In the Matter of E1lis, 258 App. Div. 558, 17 N.Y.S.2d 800 (1940).

42. In the Matter of Katzka, 225 App. Div. 250, 251-52, 232 N.Y. Supp. 575, 576-77 (1929) ; see In re Cohn, 10 Ill. $2 d$ 186, 191, 139 N.E.2d 301, 303 (1956) (censure sufficient for cooperative attorney) ; cf. In the Matter of Efros, 255 App. Div. 974, 8 N.Y.S.2d 83 (1938) ; Matter of Levy, 228 App. Div. 249, 239 N.Y. Supp. 377 (1930). Compare In the 
In view of the alternative means for securing the cooperation of witnesses at a judicial inquiry, the necessity for resorting to a "duty of candor" is less than manifest. Until this necessity is demonstrated more convincingly than it was in Cohen, a lawyer's membership in the bar should not be withdrawn for exercising the privilege against self-incrimination.

Matter of Landsman, 250 App. Div. 414, 294 N.Y. Supp. 180 (1937) ("resisted the charges"-disbarred for solicitation), with In the Matter of Mendelsohn, 250 App. Div. 417, 294 N.Y. Supp. 193 (1937) ("frankly admitted" guilt-five year suspension for solicitation and bribery) (same day, same court). 